\title{
Research on the Influence of Public Art on City Image*
}

\section{Jie $\mathbf{W u}$}

Nantong University, Nantong, China

Email:mlbsabc@sina.com

How to cite this paper: $\mathrm{Wu}, \mathrm{J} .(2016) \mathrm{Re}$ search on the Influence of Public Art on City Image. Journal of Building Construction and Planning Research, 4, 219-224. http://dx.doi.org/10.4236/jbcpr.2016.44014

Received: September 12, 2016

Accepted: October 11, 2016

Published: October 14, 2016

Copyright $\odot 2016$ by author and Scientific Research Publishing Inc. This work is licensed under the Creative Commons Attribution International License (CC BY 4.0).

http://creativecommons.org/licenses/by/4.0/

\section{Abstract}

With the integration of global economy, the urbanization process in our country develops rapidly. It appears particularly important to build city image. As manifestation of city characteristics, it reflects spiritual outlook of a city. More importantly, it is the requirement for unremitting self improvement in urbanization development. Public art embodies spirit and life style of a city. As a product of modern urban form, it has close relationship with the shaping of city image. This article researches on relevance between public art construction and city image shaping, according to general situation of public art construction in Nantong city, and discusses the influence of them. The aim of this article is to promote the shaping of city image more effectively.

\section{Keywords}

Public Art, City Image, Public Space, Relevance

\section{Introduction}

As a huge complex, city gathers multiple elements such as humanity, economy, customs, environment and landscape. With the development of society, the growth of city transits from economic layer to culture civilization construction layer. People are pursuing more delicate life and caring more about taste and quality of life, so an increasing number of people hope to feel strong artistic atmosphere in cities. However, in many cities of our country, urban commercial planning and construction are booming. The pursuit for beauty establishes on the basis of economic construction. These make cities lose characteristics and features. Therefore, the exploration on the relevance between public art construction and city image should become one of the hot issues that people pay attention to. Besides, cities also need to keep characteristics and features in the ^Fund Project: Nantong Social Science Fund Project (No.: 2016BNT028). 
rapid development. As a characteristic city in the southeast of Jiangsu, Nantong city is near the sea and the Yangtze River, with unique customs and abundant tourist resources. So the shaping of city image should be more distinctive. It needs to depend on public art construction to a larger extent.

\section{Urban Public Art}

\subsection{Concept of Urban Public Art}

In English, it is called "Public Art". From its Chinese character, it emphasizes the participation and interaction of the public. Public art cannot be called peculiar artistic expression. It belongs to comprehensive concept including multiple types, disciplines and types of work, involving extensive scope, so no scholar gives a unified specific explanation [1]. In broad sense, public art refers to artistic form of public place and space in general and its concrete contents can be extended; in narrow sense, it is formative arts focusing on appreciation. It has open characteristic as well as essential attributes of art.

\subsection{Characteristics of Urban Public Art}

Urban public art has several typical characteristics, including artistry, expression diversity, publicity and specific field property. Its artistry and expression diversity show that it doesn't have specific pattern of manifestation and style, but it can combine diversified artistic forms, including building, multimedia, painting, device and sculpture. Any kind of means of expression needs to combine with technology and art, aesthetics and science [2]. Besides, when designing, artists shall consider whether the art coordinates with city characteristics and conforms to local historic culture, emotional needs of the citizens and their receptivity for public art; as the most prominent feature of public art, publicity includes the meaning of public places and urban citizens exchange information and enter and leave the city freely. The publicity of public art shall embody the publicity of artistic works in public spaces; the Bourdieu sociology theory expounds the concept of "field domain". We call the unity of individuals and all places surrounding them "Life Circle" [3]. Public art has specific field property. If a public artistic work is not placed in proper place, although it has sense of beauty, it cannot bring emotional resonance for the audiences. In this way, it cannot promote public art to create social atmosphere and represent city image.

\section{City Image}

\subsection{The Concept of City Image}

The word "image" appeared early in the Han dynasty. Some literatures explain it as "shape and appearance of things". Later, scholars use "image" to refer to entity image of people or things. It has dual meanings. On one hand, it can refer to things of objective existence. It can be depicted, observed and perceived and give people visual input; on the other hand, it can refer to image information. It is realized through combination of sensory system and nerve cell. City image can be explained as sensory information after absorbing urban public art, including all the understanding information of urban pub- 
lic culture through cultural background and history of the city [4]. In city space, public art such as road, bridge, street lamp, bus stop and sculpture has unique feature. The public will produce direct sensory experience when perceiving public art in the space. Because of individual differences, people hold different subjective understandings or objective understandings toward public art, so the public have different understandings for city image.

City image is the soul of a city. Its uniqueness, sense of beauty and cultural context decide the appearance of a city. With the increase of travel experiences, people have increasingly strong feeling toward city image. Public art is gradually popularized because it can improve city grade and connotation. Meanwhile, it has become an important topic of city image construction, realizing landscape and humanistic value of city. It is the product of urban culture and life style. Nowadays, under the impact of economy, city image can attract foreign investment and effective tourist resources. To develop steadily, cities need to shape good city image.

\subsection{The Characteristics of City Image}

City image has three characteristics, namely integrality, long-term nature and otherness. The integrality means the impression that a city leaves on the public is integral. It cannot be embodied through urban fragments or other individual elements. This understanding is an overall recognition through interaction of urban public art. Schelling, a German scholar once elaborated in his Philosophy of Art that "maybe individual beauty will move people, but only the integral real artistic work can reveal the beauty. Therefore, people without holistic concept cannot judge artistic work very well" [5]. The formation of city image needs to go through a long process. It is inherited and developed constantly with evolution of history, culture and customs of cities. Many things can be preserved for a very long period of time. It has relative stability for city image and belongs to long term nature of city image, such as city image of headstream of the four ancient civilizations in Ancient Egypt. As one of the main headstreams of western civilization, Ancient Greek has special image. The integrality makes the city produce stable characteristics. The otherness of city image is obvious. The geographical condition, natural environment, historical culture and customs of each city are different, with different features and individuality. The character and individuality of cities are manifested. Except for the vitality, to shape city image successfully, a city shall integrate with the diversified factors, deepen understanding, and avoid repetition and plagiarism by all means.

\section{Shaping of City Image by Public Art and Design}

\subsection{Shaping of Urban Civilized Image by Public Art}

The most direct way of understanding for city image needs the transmission of sensory information. The storage of sensory information in human brain is related to logical thinking curve of human. In order to leave a deep impression on the public, each city needs to intensify the shaping of urban civilized image, thus can influence the curve of 
human thinking and effectively strengthen the transmission and storage of sensory information. The shaping of urban civilized image mainly includes the shaping of urban historical civilization, urban modern civilization and regional style.

As a special historical public art, urban historical civilization represents the basic connotation of a city. It is mainly embodied on public art elements such as museum, cultural corridor, buildings and sculpture and statue, so the shaping of urban historical civilization shall pay attention to it. Museum bears the development history of a city and reflects the trace of time. People can understand historical culture and development history more deeply through visiting museum. In addition, the storage of sensory information can make city image remained effectively in the memory of people [6]. As a common display platform of culture, cultural corridor mainly exists in public spaces such as parks and squares with large number of audiences. It shows regional culture and can give direct sense judgment to the public. Buildings which embody historical public art need to have its uniqueness. It needs longer time to accumulate. As common public artistic works, sculptures and statues are varied in different cities.

Compared with historical civilization, modern civilization of cities mainly embodies living standards and quality of citizens at the present stage. It is a new civilization produced under rapid development of industry. It requires the design of public art to consider the public pay more and more attention to the pursuit of spiritual civilization. It is also the embodiment of living standards and quality of citizens. There are many means of expression of modern civilization. The modern transportation, trash can, street greening and public guide signs of a city embody modern civilization. Cities also need to transmit civilization through public art.

Each city has unique regional style because of geographical location and natural environment. Our country has vast territory and abundant resources. Differences between the south and the north are obvious. Cities near the mountain and by the river have unique features. Citizens living in coastal cities accept the culture of sea. They think the sea fosters them. People living in highland are inclined to appreciate the culture of mountain and they think the mountain gives them everything. These are unfamiliar to people who live in inland. Nantong is a coastal city. People's understanding and respect for the sea also reflect the civilization of this city.

\subsection{Shaping of Urban Sensory Image by Public Art}

Public art has a great influence on urban sensory image. It bears the beauty of the look of cities, functional image of cities and the shaping of economic image of cities. The vitality of a city is also embodied in these aspects. Therefore, as a carrier of communication, public art shall embody characteristics.

The look of a city is the top priority that each city strives to forge. Everyone has his heart in beautiful things. For the public, living in a beautiful city is eyeable. It is also the most direct sensory image of cities. As an important part of modern city image, public art can create the beauty of a city. It shall embody tangible beauty and have cultural values, promoting the formation of its inner beauty. External and internal cultivation 
embodies the charm of public art [7]. The roads, street lamps, buildings and grasslands of a city bring the public sensory beauty. These may be dull with single design, but it will produce different visual impacts when combining them together, such as the Huanxi Cultural Square in Nantong city. No city lacks squares. It is an important public space. The Huanxi Cultural Square is built near the riverside. As an important part of Haohe scenic spot, except for the common functions, it includes music fountain, open stage, green ornamental and lamps and lanterns as well as benches. All of them have great originality and create a comfortable ambience. The combination of high technology and aesthetics makes it profound and charming, giving people external sensory beauty.

City is an entirety of people's living space. The shaping of cities focuses on meeting the requirements of people in life and development. With continuous improvement of economic level, people also ceaselessly pursue better living and development opportunities. It makes the shaping of cities grow constantly [8]. The shaping of functional image of cities is mainly embodied in public art layout and structural arrangement of urban functional areas. Living space, commercial space and entertainment space all belong to urban functional areas. The embodiment of public art in living space can improve living quality of residents. Moreover, it promotes residents to pursue interior quality continuously. Commercial space mainly provides places for people to exchange materials in daily life. Public art mainly serves as a foil in it. It shall express an open and peaceful commercial atmosphere. The image-building of entertainment space shall be diversified, so people can feel relaxed and pleasant. At the meantime, it should exert image of entertainment function and avoid concept guiding.

Nowadays, people pay attention to the economic vitality of a city. The economic image of a city is also an important part of city image. The shaping of urban economic image by public art mainly embodies in two aspects, including integrity of the design of public elements and its quality. The height and difficulty of buildings in core area, the degree of prosperity of commercial space, the green coverage ratio of urban road and fitness facility and layout of leisure space are reference indexes of economic image. The public art design shall not only embody independent sensory image but also show integral effect. In this way, it can shape economic image of a city effectively. As a city built in an all-round way after the reform and opening, Shenzhen city has a speed of development that shocks the world. It has reached advanced level in China in public art design and layout. The integrity of public art and quality pursuit has reached unprecedented height. In recent years, many cities begin to build central business district (CBD). The CBD in Nantong also appears with it. The selection of geographic position and layout of commercial space bases on overall planning. The arrangement of public art is also well-designed. It reflects the continuous economic development of Nantong city. In addition, it shows positive effects brought by public art for the image shaping of Nantong city.

\section{Conclusions}

The development of cities will never stop. The pursuit of public art will improve uncea- 
singly. With the update of science and technology, public art will constantly integrate with other disciplines to produce new means of expression. It will bring better opportunity for the shaping of city image. Nowadays, under the impact of economic development, the development patterns of many cities are the same. Some cities lose characteristics. Furthermore, the public are not able to understand city image clearly. It shows these cities are lack of vitality.

This article expounds public art and city image and uses some examples in Nantong city, and discusses the public art influences the shaping of city image from many aspects, including civilized image and sensory image of cities. It also includes specific city images such as function, economy, appearance, history and modernization of cities. From the perspective of the development of cities, public art is a means of expression of city image as well as one of the impetuses to promote integrated development of cities. Paying attention to public art construction can effectively boost the shaping of city image. Besides, the public shall not get lost in pursuing public art. Each city should integrate historical background and regional features with modern society, design the public art that can be understood by local people very well, and then better drive the shaping of city image unremittingly.

\section{References}

[1] Ma, J.J. (2016) Research on Public Space Planning of Middle School Campus Experience Type on the Basis of Behavior Pattern of Users. Shandong Jianzhu University.

[2] Shao, Z.H. (2016) Design Research of Public Space under the Perspective of Digital Image Art. Henan University of Technology.

[3] Wang, Y.Q. (2016) Research on Planning of Guiding Sign System of Urban Walk Public Space. North China University of Technology.

[4] Wang, L.M. (2016) Research on Landscape Design of Rural Public Place in the Southwestern Shandong. Shandong Jianzhu University.

[5] Zhang, Y.P. and Shen, L. (2015) Urban Public Art Design in Suzhou under Cultural Background of "Su Type". Modern Decoration (Theory), No. 3.

[6] Yuan, X.L. (2016) Analysis on Characteristics of Urban Public Art Design in Shanwei. Design, No. 1.

[7] Deng, X.Y. (2014) Discussion on Function of Public Art Design in Urban Space. Yong Writers, 20.

[8] Chen, X. (2012) Urbanization Characteristics and Public Art Design-Thoughts on Urban Construction and Public Art Design of Guilin. Guilin Institute of Electronic Technology, No. 6. 
Submit or recommend next manuscript to SCIRP and we will provide best service for you:

Accepting pre-submission inquiries through Email, Facebook, LinkedIn, Twitter, etc. A wide selection of journals (inclusive of 9 subjects, more than 200 journals)

Providing 24-hour high-quality service

User-friendly online submission system

Fair and swift peer-review system

Efficient typesetting and proofreading procedure

Display of the result of downloads and visits, as well as the number of cited articles

Maximum dissemination of your research work

Submit your manuscript at: http://papersubmission.scirp.org/

Or contact jbcpr@scirp.org 